\title{
Antioxidative activity of roasted Pueraria lobata root extracts
}

\author{
Goo-Hee Choi ${ }^{1}$, Hyun Jung Kim ${ }^{1}$, In-Jae Park ${ }^{1}$, Bong-Gyun Kim ${ }^{1}$, Hoi-Yeong Kim ${ }^{2}$, \\ Jae-Hyun Jeong ${ }^{2}$, Ju-Hyun Cho ${ }^{1 *}$ \\ ${ }^{1}$ Hurum Central research institute Co., Ltd., Cheongju 28116, Korea \\ ${ }^{2}$ Food Science and Technology, Korea National University of Transportation, Jeungpyeong 27909, Korea
}

\section{로스팅 칡 추출물의 항산화 활성}

\author{
최구희 ${ }^{1} \cdot$ 김현정 $^{1} \cdot$ 박인재 $^{1} \cdot$ 김봉균 $^{1} \cdot$ 김회영 $^{2} \cdot$ 정재현 $^{2} \cdot$ 조주현 $^{1 *}$ \\ ${ }^{1}$ (주)휴럼중앙연구소, ${ }^{2}$ 한국교통대학교 식품공학과
}

\begin{abstract}
We evaluated the antioxidative activity of extracts of $P$. lobata root depending on roasting conditions. $P$. lobata roots were roasted at three different temperature at $150^{\circ} \mathrm{C}, 200^{\circ} \mathrm{C}$, and $250^{\circ} \mathrm{C}$ and three different time at 10 min, $20 \mathrm{~min}$, and $30 \mathrm{~min}$ respectively. Roasted $P$. lobata root was extracted using water at $85^{\circ} \mathrm{C}$ for $6 \mathrm{~h}$ and filtered using filter paper, followed by then evaporated $\left(12 \pm 0.3{ }^{\circ}\right.$ Brix $)$ and freeze-dried. The concentration of maker compound puerarin was determined using a high performance liquid chromatography system. 2 phenolic compounds, flavonoid contents, and antioxidant activities of the extract powder were evaluated. Puerarin contents, Phenolic compounds, and flavonoid contents of roasted $P$. lobata root were higher than those of unroasted $P$. lobata root. The results of DPPH and ABTS showed that roasted $P$. lobata root possessed higher antioxidant activity than unroasted $P$. lobata root. This study suggested that roasting process could be applied to $P$. lobata root in order to achieve its high quality and functionality.
\end{abstract}

Key words : Pueraria lobata, roasting, puerarin, antioxidant activities

\section{서 론}

칡(Pueraria lobata)은 콩과의 덩굴성 다년식물로서 한국, 중국, 만주, 대만, 극동러시아, 일본 등을 포함한 극동아시 아에 자생하고 있다. 예로부터 칡은 아시아에서 중요한 약 용식물로 사용되어왔으며, 칡의 뿌리를 생약명으로는 갈근 이라 하여, 껍질을 제거한 뿌리를 절편으로 건조한 것을 이용하며 해열, 발한 등의 감기약으로 사용하거나, 편두통, 편도선염 등에 광범위하게 사용되고 있다(1). 칡의 뿌리에 는 몇 가지의 flavonoids가 함유되어 있다고 보고되어 있으 며(2), 대표적으로 다이드진(daidzin), 다이드제인(daidzein),

*Corresponding author. E-mail : dusvnd608@hurumcorp.com Phone : 82-43-217-1077, Fax : 82-43-217-1088

Received 7 April 2017; Revised 25 April 2017; Accepted 26 April 2017.

Copyright (c) The Korean Society of Food Preservation. All rights reserved. 제니스틴(genistin), 제니스테인(genistein), 푸에라린(puerarin) 등과 같은 이소플라본이 함유되어 있다(3). 특히 puerarin은 칡의 항산화성분이며, 카테킨 성분은 간 기능을 회복시키 는 성분으로 알려져 있다(4-8).

차의 제조공정에 있어서 로스팅 처리는 식품의 화학적 성분 조성, 물리적 성질, 그리고 색깔, 향기, 조직감과 같은 관능적 품질 요소에 영향을 미치는 것으로 보고되고 있다 (9-11). Yoon 등(12)은 보리의 로스팅 조건이 보리차의 점도 및 맛과 냄새 등 관능적 특성에 대한 영향을 보고하였으며, $\mathrm{Ha}$ 등(13)은 숭늉제조용 찐백미, Lee 등(14)은 미숙보리 곡립의 로스팅 조건에 따른 색도와 환원당 및 아미노산 함량의 변화를 보고하였다. Ayatse 등(15)은 옥수수의 로스 팅 과정 중 일반성분, 무기질, 아미노산함량 변화에 대하여 보고하였으며 Kunsch 등(16)은 밤의 로스팅 과정 중 환원 당, 지방산 함량 변화를 측정하고 이들 성분변화와 관능평 가와의 상관관계에 대하여 보고하였다.

본 연구에서는 칡에 대하여 로스팅 온도, 로스팅 시간 
등에 따른 지표성분 함량 분석, 항산화효과 등을 확인하여 기능성 식품 및 다류 소재 개발을 하고자 하였다.

\section{재료 및 방법}

\section{재료 및 가공조건}

본 실험에 사용한 칡은 2015년에 전라남도 소재의 남원 원 예농협으로부터 구매하여 사용하였다. 구매한 칡은 세 척, 건조, 세절 후에 1 차 증숙 공정으로 증숙기에서 $121^{\circ} \mathrm{C}$, 30 분 동안 증숙한 후, 건조온도 $25^{\circ} \mathrm{C}$ 의 건조기에서 1 일간 건조하였다. 2 차 증숙 공정으로 $80^{\circ} \mathrm{C}$ 의 증숙기에서 100 분 동안 증숙 한 후, $25^{\circ} \mathrm{C}$ 의 건조기에서 1 일간 건조하였다. 건조된 칡은 세 가지 온도조건 $\left(150^{\circ} \mathrm{C}, 200^{\circ} \mathrm{C}, 250^{\circ} \mathrm{C}\right)$ 에서 각각 10 분, 20 분, 30 분 로스팅을 수행하였고, $35^{\circ} \mathrm{C}$ 내에서 3 일간 숙성하였다.

\section{시료의 제조}

각각의 조건에서 로스팅한 칡을 원물에 10 배수의 증류수 를 넣고 환류 추출장치에서 $95^{\circ} \mathrm{C}$ 의 온도로 6 시간동안 추출 하였으며, 2 회 실시하였다. 1 차 및 2 차에 얻어진 추출물을 혼합하여 filter paper(ADVANTEC, Tokyo, Japan)로 여과한 다음 일정농도 $\left(12 \pm 0.3{ }^{\circ} \mathrm{Brix}\right)$ 까지 농축(VV20, Heidolph, Schwabach, Germany)한 후 동결건조(MCFD5510, Il-sin, Dongducheon, Korea)하여 열수추출 분말시료를 얻었으며, 이렇게 얻어진 분말시료는 control(칡 원물), PL-15-1(칡 15 $0^{\circ} \mathrm{C}, 10$ 분간 로스팅), $\mathrm{PL}-15-2$ (칡 $150^{\circ} \mathrm{C}, 20$ 분간 로스팅), PL-15-3(칡 $150^{\circ} \mathrm{C}, 30$ 분간 로스팅), PL-20-1(칡 $200^{\circ} \mathrm{C}, 10$ 분 간 로스팅), PL-20-2(칡 $200^{\circ} \mathrm{C}, 20$ 분간 로스팅), $\mathrm{PL}-20-3$ (칡 $200^{\circ} \mathrm{C}, 30$ 분간 로스팅), PL-25-1(칡 $250^{\circ} \mathrm{C}, 10$ 분간 로스팅), PL-25-2(칡 $250^{\circ} \mathrm{C}, 20$ 분간 로스팅), PL-25-3(칡 $250^{\circ} \mathrm{C}, 30$ 분 간 로스팅)로 각각의 실험 방법에 따라 전처리하여 사용하 였다.

\section{지표성분 분석 \\ Puerarin(Tokyo Chemical, Tokyo, Japan) $10 \mathrm{mg}$ 을 취하여 methanol(JT baker, Avantor Performance Materials, PA, USA)을 가해 $100 \mathrm{~mL}$ 로 정용하여 표준원액으로 하였다. 표준원 액을 $10 \mathrm{~mL}$ 용량플라스크에 methanol을 사용하여 $50,25,10,5 \mathrm{ppm}$ 의 표준용액을 제조하였다. 또한 P. lobata 열수추출물 10 종은 약 $100 \mathrm{mg}$ 의 무게를 칭량 후, methanol 을 $15 \mathrm{~mL}$ 넣어 30 분간 ultrasonic cleaner(Powersonic 420, Hwashin Tech, Daegu, Korea)에서 초음파 추출한 다음 20 분 간 방냉 후, $25 \mathrm{~mL}$ 로 정용 후 4배 희석하여 $0.45 \mu \mathrm{m}$ membrane filter(ADVANTEC, Dublin, CA, USA)로 여과 후 시험용액으로 사용하였다. \\ 상기 조제된 표준용액과 시험용액을 HPLC(Waters 2695,}

Milford, MA, USA), Photodiode Array Detector(Waters 996, Milford, MA, USA)를 사용하여 분석하였다. 고정상으로는 Shiseido $\mathrm{C}_{18}(5 \mu \mathrm{m} 4.6 \times 250 \mathrm{~mm}$, Shiseido, Tokyo, Japan) 컬럼 을 사용하였고, 이동상은 methanol과 water가 $25: 75$ 의 비율 로 유량 $1.0 \mathrm{~mL} / \mathrm{min}$ 로 설정하여 $254 \mathrm{~nm}$ 파장에서 분석 하였 다. Puerarin의 검량선을 작성하고 시험용액에 함유된 함량 값을 계산하였다. 검량선의 회귀방정식은 $\mathrm{y}=0.000337 \mathrm{x}$ $0.000152\left(\mathrm{R}^{2}=0.9998\right)$ 로 고도의 유의적인 정의 상관관계가 있었다.

\section{총 페놀 함량}

총 페놀 함량은 Folin-Ciocalteu's phenol reagent가 페놀성 화합물에 의해 몰리브덴 청색으로 환원되는 원리로 측정하 였다. 각 시료 $1 \mathrm{~mL}$ 에 $2 \%$ Folin-Ciocalteu's phenol regent $1 \mathrm{~mL}$ 을 첨가한 후 $10 \% \mathrm{Na}_{2} \mathrm{CO}_{3}$ 용액을 $1 \mathrm{~mL}$ 을 넣고 혼합하 여 상온에서 1 시간 동안 방치하였다. 그 후 반응액의 흡광도 를 microplate reader(Molecular Devices, Sunnyvale, CA, $\mathrm{USA}$ )를 이용하여 $750 \mathrm{~nm}$ 에서 측정하였다. 표준물질로 gallic acid를 이용하였으며 표준 검량 곡선으로부터 총 페놀 함량을 계산하였다.

\section{총 플라보노이드 함량}

총 플라보노이드 함량은 시료를 각각 $1 \mathrm{mg} / \mathrm{mL}$ 의 농도로 제조한 뒤 증류수 $1.25 \mathrm{~mL}$ 를 가하고 $5 \% \mathrm{NaNO}_{2}$ 용액 75 $\mu \mathrm{L}$ 를 넣고 5 분간 방치한 후, $10 \% \mathrm{AlCl}_{3} \cdot 6 \mathrm{H}_{2} \mathrm{O}$ 용액 150 $\mu \mathrm{L}$ 를 가하고 다시 6분간 방치하였다. 위 반응액에 $1 \mathrm{M}$ $\mathrm{NaOH} 500 \mu \mathrm{L}$ 와 증류수 $275 \mu \mathrm{L}$ 를 가한 후 $510 \mathrm{~nm}$ 에서 흡광도를 측정하였다. 표준물질은 Rutin(Sigma Aldrich Chemical Co., St. Louis, MO, USA)을 사용하여 표준검량선 을 작성 후 추출물의 총 플라보노이드 함량은 $\mu \mathrm{g}$ rutin equivalent(RE)/g으로 나타내었다.

\section{ABTS 라디칼 소거능}

$7 \mathrm{mM}$ ABTS 용액과 $2.45 \mathrm{mM}$ potassium persulfate를 혼합 하여 빛을 차단한 상태로 16 시간동안 상온에서 반응시켜 $\mathrm{ABTS}$ 양이온을 형성시킨 후 흡광도 값이 $0.70 \pm 0.02$ 가 되도 록 무수에탄올을 이용하여 조절하였다. 시료 $10 \mu \mathrm{L}$ 와 900 $\mu \mathrm{L}$ 의 희석된 $\mathrm{ABTS}$ 용액을 첨가하고 6 분 동안 반응시켜 microplate reader의 $734 \mathrm{~nm}$ 에서 흡광도를 측정하였다. ABTS 라디칼 소거능은 아래의 식을 이용하여 계산하였다.

$\mathrm{ABTS}$ 라디칼 소거능 $(\%)=1-\left(\frac{\mathrm{A}_{\text {sample }}}{\mathrm{A}_{\text {control }}}\right) \times 100$

$\mathrm{A}_{\text {sample }}$ : 시료군 흡광도

$\mathrm{A}_{\text {control }}$ : 대조군 흡광도 


\section{$\mathrm{DPPH}$ 라디칼 소거능}

농도별로 나눈 시료 $200 \mu \mathrm{L}$ 와 $0.4 \mathrm{mM} \mathrm{DPPH}$ 용액 800 $\mu \mathrm{L}$ 을 첨가하고 10 분 동안 반응시켜 microplate reader (Molecular Devices)의 $517 \mathrm{~nm}$ 에서 흡광도를 측정하였다. $\mathrm{DPPH}$ 라디칼 소거능은 아래의 식을 이용하여 계산하였다.

DPPH 라디칼 소거능(\%)=1-( $\left.\frac{\mathrm{A}_{\text {sample }}}{\mathrm{A}_{\text {control }}}\right) \times 100$

$\mathrm{A}_{\text {sample }}$ : 시료군 흡광도

$\mathrm{A}_{\text {control }}$ : 대조군 흡광도

\section{통계처리}

실험에서 얻어진 통계적 유의성은 SPSS(statistical package for social sciences, SPSS INC, ver.19.0, Chicago, IL, USA) package program을 이용하여 실험군 당 평균과 표준편차로 표시하였고, Duncan's multiple range test $(\mathrm{p}<0.05)$ 에 의해 유의성을 검정하였다.

\section{결과 및 고찰}

\section{로스팅 조건에 따른 추출 및 동결건조 수율}

로스팅의 온도와 시간을 달리하여 로스팅한 칡 소재에 추출용매로 물을 사용하여 추출, 농축, 동결건조를 실시하 여 얻어진 수율 $(\%)$ 은 Table 1 과 같다. Control의 수율은 $23.55 \pm 0.45 \%$ 로 나타났으며, $150^{\circ} \mathrm{C}$ 에서 로스팅한 경우, 로 스팅 시간이 증가함에 따라 각각의 수율 $(26.26 \pm 0.39 \%$, $26.38 \pm 0.39 \%, 27.36 \pm 0.45 \%)$ 이 증가하였다. $200^{\circ} \mathrm{C}$ 에서 로스 팅한 경우의 수율 $(28.01 \pm 0.11 \%, 28.61 \pm 0.31 \%, 28.75 \pm 0.33 \%)$

Table 1. Puerarin contents and yields of rosting Pueraria lobata root extract (after freeze drying)

\begin{tabular}{ccccc}
\hline Samples & $\begin{array}{c}\text { Rosting } \\
\text { temperature }\left({ }^{\circ} \mathrm{C}\right)\end{array}$ & $\begin{array}{c}\text { Rosting time } \\
(\mathrm{min})\end{array}$ & $\begin{array}{c}\text { Puerarin } \\
\text { contents }(\mathrm{mg} / \mathrm{g})\end{array}$ & $\begin{array}{c}\text { Extract } \\
\text { yield }(\%)\end{array}$ \\
\hline Control & 0 & 0 & $72.19 \pm 2.04^{1 \mathrm{e} 22}$ & $23.55 \pm 0.45^{\mathrm{e}}$ \\
PL-15-1 & 150 & 10 & $83.25 \pm 0.54^{\mathrm{d}}$ & $26.26 \pm 0.39^{\mathrm{d}}$ \\
PL-15-2 & 150 & 20 & $88.89 \pm 0.41^{\mathrm{b}}$ & $26.38 \pm 0.39^{\mathrm{d}}$ \\
PL-15-3 & 150 & 30 & $88.18 \pm 0.21^{\mathrm{b}}$ & $27.36 \pm 0.45^{\mathrm{c}}$ \\
PL-20-1 & 200 & 10 & $85.75 \pm 1.49^{\mathrm{c}}$ & $28.01 \pm 0.11^{\mathrm{b}}$ \\
PL-20-2 & 200 & 20 & $91.83 \pm 0.22^{\mathrm{a}}$ & $28.61 \pm 0.31^{\mathrm{a}}$ \\
PL-20-3 & 200 & 30 & $89.24 \pm 1.41^{\mathrm{ab}}$ & $28.75 \pm 0.33^{\mathrm{a}}$ \\
PL-25-1 & 250 & 10 & $89.66 \pm 0.35^{\mathrm{ab}}$ & $27.90 \pm 0.39^{\mathrm{b}}$ \\
PL-25-2 & 250 & 20 & $91.42 \pm 2.16^{\mathrm{a}}$ & $28.03 \pm 0.50^{\mathrm{b}}$ \\
PL-25-3 & 250 & 30 & $89.72 \pm 1.91^{\mathrm{ab}}$ & $28.94 \pm 0.31^{\mathrm{a}}$ \\
\hline
\end{tabular}

\footnotetext{
${ }^{1)}$ Value are mean $\pm \mathrm{SD}(\mathrm{n}=3)$.

${ }^{2 a t}$ Means in the same column not sharing a common letter are significantly different $(\mathrm{p}<0.05)$ by Duncan's multiple test.
}

과 $250^{\circ} \mathrm{C}$ 에서 로스팅한 경우의 수율 $(27.90 \pm 0.39 \%, 28.03 \pm$ $0.50 \%, 28.94 \pm 0.31 \%$ )도 로스팅 시간이 증가함에 따라 각각 의 수율이 증가함을 알 수 있었다. 최적 수율을 보이는 로스 팅 조건은 $200^{\circ} \mathrm{C}$ 에서 20 분, 30 분 그리고, $250^{\circ} \mathrm{C}$ 에서 30 분으 로 나타났으며, 로스팅 하지 않은 control에 비해 로스팅한 시료들에서 모두 수율이 유의하게 증가함을 알 수 있었다.

\section{로스팅 조건에 따른 puerarin 함량}

$\mathrm{Oh}$ 등(6)이 칡뿌리 중의 항산화 성분에 대하여 분석한 자료에 의하면 플라보노이드 성분의 일종인 puerarin으로 확인 동정되었으며, 주요한 폴리페놀 물질이라고 보고하였 다. 또한 대한약전에서 칡의 지표물질로 puerarin으로 제시 되어 있다. 이에 본 연구는 로스팅을 통하여 칡 가공연구에 있어서 개발소재의 표준화를 위하여 지표성분으로 puerarin 으로 설정하였다.

칡의 지표성분인 puerarin 함량에 대해 로스팅 조건을 달리한 칡 추출물을 분석한 결과를 Table 1 에 나타내었다. 로스팅 전의 칡 추출물(control)의 puerarin 함량은 $72.19 \pm$ $2.04 \mathrm{mg} / \mathrm{g}$ 으로 나타났으며, $150^{\circ} \mathrm{C}$ 에서 로스팅한 경우, 로스 팅 시간 10 분, 20 분, 30 분 모두에서 대조군에 비해 puerarin 함량 $(83.25 \pm 0.54,88.89 \pm 0.41,88.18 \pm 0.21 \mathrm{mg} / \mathrm{g})$ 이 증가하였 다. $200^{\circ} \mathrm{C}$ 에서 로스팅한 경우의 puerarin 함량 $(85.75 \pm 1.49$, $91.83 \pm 0.22,89.24 \pm 1.41 \mathrm{mg} / \mathrm{g}$ )과 $250^{\circ} \mathrm{C}$ 에서 로스팅한 경우 의 puerarin 함량 $(89.66 \pm 0.35,91.42 \pm 2.16,89.72 \pm 1.91 \mathrm{mg} / \mathrm{g})$ 도 로스팅 시간 10 분, 20 분, 30 분 모두에서 대조군에 비해 증가함을 알 수 있었다. Puerarin 함량이 가장 많은 로스팅 조건은 $200^{\circ} \mathrm{C}$ 에서 20 분, $250^{\circ} \mathrm{C}$ 에서 30 분으로 나타났으며, 로스팅 하지 않은 control에 비해 로스팅한 시료들에서 모두 puerarin 함량이 유의하게 증가함을 알 수 있었다. Lee 등 (17)은 열풍건조 후 로스팅 처리한 씀바귀의 총 폴리페놀 함량이 증가함을 보고하였으며, Hong 등(18)은 로스팅 처 리한 치커리뿌리에서 페놀성 화합물의 함량이 증가한다고 보고하였다. 이와 같이 로스팅 처리한 칡에서 대표적인 폴 리페놀인 puerarin의 함량이 증가하는 것은 아마도 로스팅 공정에 따른 가열처리에 의해 칡의 내부 조직의 파괴로 인하여 페놀성 화합물이 쉽게 유리되어 함량이 증가하는 것으로 판단된다.

\section{총 페놀 및 플라보노이드 함량}

페놀성 화합물은 식물계에 널리 분포되어 물질로 다양한 구조와 분자량을 가지며 페놀성 화합물의 phenol hydroxyl 기를 통해 항산화, 항암 및 항균 등의 생리기능을 가지는 것으로 알려져 있다(19). 로스팅 조건에 따라 처리한 칡 열수추출물의 총 페놀 함량 및 플라보노이드 함량을 측정한 결과는 Table 2 와 같다. 로스팅 처리에 따라 총 페놀 및 플라보노이드 함량이 증가하는 경향을 나타내었는데, 이 는 Hong 등(18)과 Lee 등(20)의 연구 결과와 같은 경향을 
보였다.

Control의 총 페놀 함량은 $40.15 \pm 2.47 \mathrm{mg} \mathrm{GAE} / \mathrm{g}$ 으로 나 타났으며, $150^{\circ} \mathrm{C}$ 에서 로스팅한 경우, 로스팅 시간이 증가함 에 따라 각각의 총 페놀 함량 $(40.24 \pm 0.53,42.70 \pm 0.81$, $42.78 \pm 0.30 \mathrm{mg} \mathrm{GAE} / \mathrm{g}$ )이 증가하는 경향이 나타났다. $200^{\circ} \mathrm{C}$ 에서 로스팅한 경우의 총 페놀 함량 $(40.54 \pm 0.07,42.81 \pm$ $0.43,42.89 \pm 0.24 \mathrm{mg} \mathrm{GAE} / \mathrm{g}$ )과 $250^{\circ} \mathrm{C}$ 에서 로스팅한 경우의 총 페놀 함량 $(42.92 \pm 0.27,45.73 \pm 0.41,45.99 \pm 0.48 \mathrm{mg}$ $\mathrm{GAE} / \mathrm{g}$ )도 로스팅 시간이 증가함에 따라 각각의 함량이 증 가함을 알 수 있었다.

Control의 총 플라보노이드 함량은 $12.72 \pm 0.05 \mathrm{mg} \mathrm{RE} / \mathrm{g}$ 으로 나타났으며, $150^{\circ} \mathrm{C}$ 에서 로스팅한 경우, 로스팅 시간이 증가함에 따라 각각의 총 플라보노이드 함량 $(14.70 \pm 0.23$, $16.94 \pm 0.33,16.89 \pm 0.38 \mathrm{mg} \mathrm{RE} / \mathrm{g}$ )이 증가하는 경향이 나타 났다. $200^{\circ} \mathrm{C}$ 에서 로스팅한 경우의 총 플라보노이드 함량 $(15.94 \pm 0.65,17.31 \pm 0.09,17.50 \pm 0.21 \mathrm{mg} \mathrm{RE} / \mathrm{g})$ 과 $250^{\circ} \mathrm{C}$ 에서 로스팅한 경우의 총 플라보노이드 함량 $(16.49 \pm 0.25,16.60 \pm$ $0.13,17.53 \pm 0.17 \mathrm{mg} \mathrm{RE} / \mathrm{g}$ )도 로스팅 시간이 증가함에 따라 각각의 함량이 증가함을 알 수 있었다. 총 페놀 함량이 가장 많은 로스팅 조건은 $250^{\circ} \mathrm{C}$ 에서 20 분, 30 분으로 나타났으며, 총 플라보노이드 함량이 가장 많은 로스팅 조건은 $200^{\circ} \mathrm{C}$ 에 서 20 분, 30 분 그리고, $250^{\circ} \mathrm{C}$ 에서 30 분으로 나타났으며, control에 비해 로스팅한 시료들에서 모두 총 페놀 및 플라 보노이드 함량이 유의하게 증가함을 알 수 있었다. 이와 같은 함량 증가는 로스팅 온도가 높아짐에 따라, 로스팅 시간이 늘어남에 따라 두드러지게 나타났다. 이러한 결과 는 앞서 언급한 것과 마찬가지로 가열처리에 의해 칡의 내부 조직의 파괴로 인하여 추출시 페놀 화합물과 같은 성분들이 쉽게 유리되기 때문인 것으로 판단된다.

Table 2. Total phenolic and total flavonoid contents of rosting Pueraria lobata root extract (after freeze drying)

\begin{tabular}{ccc}
\hline Samples & $\begin{array}{c}\text { Total phenolic contents } \\
(\mathrm{mg} \mathrm{GAE} / \mathrm{g})\end{array}$ & $\begin{array}{c}\text { Total flavonoid contents } \\
(\mathrm{mg} \mathrm{RE} / \mathrm{g})\end{array}$ \\
\hline Control & $40.15 \pm 0.47^{1 \mathrm{)} 2)}$ & $12.72 \pm 0.05^{\mathrm{e}}$ \\
PL-15-1 & $40.24 \pm 0.53^{\mathrm{c}}$ & $14.70 \pm 0.23^{\mathrm{d}}$ \\
PL-15-2 & $42.70 \pm 0.81^{\mathrm{b}}$ & $16.94 \pm 0.33^{\mathrm{ab}}$ \\
PL-15-3 & $42.78 \pm 0.30^{\mathrm{b}}$ & $16.89 \pm 0.38^{\mathrm{ab}}$ \\
PL-20-1 & $40.54 \pm 0.07^{\mathrm{c}}$ & $15.94 \pm 0.65^{\mathrm{c}}$ \\
PL-20-2 & $42.81 \pm 0.43^{\mathrm{b}}$ & $17.31 \pm 0.09^{\mathrm{a}}$ \\
PL-20-3 & $42.89 \pm 0.24^{\mathrm{b}}$ & $17.50 \pm 0.21^{\mathrm{a}}$ \\
PL-25-1 & $42.92 \pm 0.27^{\mathrm{b}}$ & $16.49 \pm 0.25^{\mathrm{b}}$ \\
PL-25-2 & $45.73 \pm 0.41^{\mathrm{a}}$ & $16.60 \pm 0.13^{\mathrm{b}}$ \\
PL-25-3 & $45.99 \pm 0.48^{\mathrm{a}}$ & $17.53 \pm 0.17^{\mathrm{a}}$ \\
\hline
\end{tabular}

${ }^{1)}$ Value are mean $\pm \mathrm{SD}(\mathrm{n}=3)$.

${ }^{2) a c}$ Means in the same column not sharing a common letter are significantly different $(\mathrm{p}<0.05)$ by Duncan's multiple test.

\section{항산화 효능}

로스팅 처리 조건에 따라 추출한 칡 추출물의 항산화 효능을 측정한 결과는 Table 3 과 같다. 시료의 특성에 따라 $\mathrm{DPPH}$ 라디칼과 $\mathrm{ABTS}$ 라디칼과의 결합 정도가 다를 수 있어(21), 본 연구에서는 DPPH 및 ABTS 라디칼 소거능을 모두 분석하였다. $\mathrm{ABTS}$ 라디칼 소거능의 경우, control에서 $66.04 \pm 0.10 \%$ 로 나타났으며, $150^{\circ} \mathrm{C}$ 에서 로스팅한 경우, 로 스팅 시간 10 분, 20 분, 30 분 모두에서 대조군에 비해 $\mathrm{ABTS}$ 라디칼 소거능 $(73.36 \pm 0.18 \%, 75.95 \pm 0.40 \%, 80.00 \pm 0.45 \%)$ 이 증가하였다. $200^{\circ} \mathrm{C}$ 에서 로스팅한 경우의 $\mathrm{ABTS}$ 라디칼 소거능 $(71.28 \pm 0.31 \%, 75.82 \pm 0.75 \%, 75.27 \pm 1.69 \%)$ 과 $250^{\circ} \mathrm{C}$ 에서 로스팅한 경우의 $\mathrm{ABTS}$ 라디칼 소거능 $(76.65 \pm 0.49 \%$, $74.93 \pm 0.83 \%, 75.21 \pm 0.19 \%$ )도 로스팅 시간 10 분, 20 분, 30 분 모두에서 대조군에 비해 증가함을 알 수 있었다. 또한, $\mathrm{DPPH}$ 라디칼 소거능은 일반적으로 페놀성 화합물의 함량 과 연관성이 아주 높은 것으로 알려져 있다(18). DPPH 라디 칼 소거능의 경우, control에서 $60.73 \pm 0.41 \%$ 로 나타났으며, $150^{\circ} \mathrm{C}$ 에서 로스팅한 경우, 로스팅 시간 10 분, 20 분, 30 분 모두에서 대조군에 비해 DPPH 라디칼 소거능 $(65.71 \pm 1.87 \%, 66.00 \pm 1.75 \%, 77.15 \pm 1.17 \%)$ 이 증가하였다. $200^{\circ} \mathrm{C}$ 에서 로스팅한 경우의 DPPH 라디칼 소거능 $(78.92 \pm 0.80 \%, 78.18 \pm 1.76 \%, 81.45 \pm 0.50 \%)$ 과 $250^{\circ} \mathrm{C}$ 에서 로 스팅한 경우의 $\mathrm{DPPH}$ 라디칼 소거능 $(77.97 \pm 0.33 \%$, $77.77 \pm 2.35 \%, 77.62 \pm 0.34 \%$ )도 로스팅 시간 10 분, 20 분, 30 분 모두에서 대조군에 비해 증가함을 알 수 있었다. Kim 등(21)은 검정콩을 로스팅 처리 후 항산화 효과가 증가한다 고 보고하였으며 이는 본 연구의 결과와 유사함을 알수 있었다. 전체적으로 로스팅 처리한 칡의 항산화 활성이 가 장 높은 조건은 $200^{\circ} \mathrm{C}$ 에서 20 분, 30 분으로 나타났으며, 이

Table 3. ABTS and DPPH radical scavenging activities of rosting Pueraria lobata root extract (after freeze drying)

\begin{tabular}{cccc}
\hline Samples & $\begin{array}{c}\text { Concentration } \\
(\mathrm{mg} / \mathrm{mL})\end{array}$ & $\begin{array}{c}\text { ABTS radical } \\
\text { scavenging activity }(\%)\end{array}$ & $\begin{array}{c}\text { DPPH radical } \\
\text { scavenging activity }(\%)\end{array}$ \\
\hline Control & 10 & $66.04 \pm 0.10^{1 \mathrm{l}) \mathrm{d} 2}$ & $60.73 \pm 0.41^{\mathrm{d}}$ \\
PL-15-1 & 10 & $73.36 \pm 0.18^{\mathrm{bc}}$ & $65.71 \pm 1.87^{\mathrm{c}}$ \\
PL-15-2 & 10 & $75.95 \pm 0.40^{\mathrm{b}}$ & $66.00 \pm 1.75^{\mathrm{c}}$ \\
PL-15-3 & 10 & $80.00 \pm 0.45^{\mathrm{a}}$ & $77.15 \pm 1.17^{\mathrm{b}}$ \\
PL-20-1 & 10 & $71.28 \pm 0.31^{\mathrm{c}}$ & $78.92 \pm 0.80^{\mathrm{b}}$ \\
PL-20-2 & 10 & $75.82 \pm 0.75^{\mathrm{b}}$ & $78.18 \pm 1.76^{\mathrm{b}}$ \\
PL-20-3 & 10 & $75.27 \pm 1.69^{\mathrm{b}}$ & $81.45 \pm 0.50^{\mathrm{a}}$ \\
PL-25-1 & 10 & $76.65 \pm 0.49^{\mathrm{b}}$ & $77.97 \pm 0.33^{\mathrm{b}}$ \\
PL-25-2 & 10 & $74.93 \pm 0.83^{\mathrm{bc}}$ & $77.77 \pm 2.35^{\mathrm{b}}$ \\
PL-25-3 & 10 & $75.21 \pm 0.19^{\mathrm{b}}$ & $77.62 \pm 0.34^{\mathrm{b}}$ \\
\hline
\end{tabular}

\footnotetext{
${ }^{1)}$ Value are mean \pm SD $(\mathrm{n}=3)$.

2)ad Means in the same column not sharing a common letter are significantly different $(\mathrm{p}<0.05)$ by Duncan's multiple test.
} 
러한 결과는 앞서 언급한 총 페놀함량 및 플라보노이드 함량 측정 결과와 매우 유사함을 확인하였으며, 이는 대표 적인 항산화 성분인 폴리페놀 및 플라보노이드 등의 페놀성 화합물이 로스팅 처리에 의해 증가하여 항산화 효과가 증가 되었을 것으로 사료된다(22).

\section{요 약}

본 연구에서는 기능성이 증대된 칡 소재 개발을 위하여 로스팅 조건에 따른 칡 추출물을 제조하였으며, 각 추출물 에 대한 지표성분 함량 및 항상화 활성 등을 검토하였다. 칡의 지표성분이 puerarin 함량을 로스팅 조건에 따라 분석 을 실시하였으며, 그 결과 로스팅 온도와 시간이 늘어남에 따라 puerarin 함량이 증가하는 경향을 나타내었다. 또한, 로스팅 조건에 따른 총 페놀과 플라보노이드 함량의 경우도 puerarin 함량의 결과와 마찬가지로 유사한 경향을 보이고 있었다. 항산화 활성을 평가하기 위하여 ABTS 및 DPPH 라디칼 소거능을 실시하였으며, 전체적으로 로스팅 온도와 시간이 늘어남에 따라 활성이 높아지는 경향을 보여 로스팅 처리한 칡이 일반적인 칡 보다 우수한 것으로 나타났다. 이러한 결과를 종합하여 볼 때 칡을 활용한 기능성 식품 및 다류 개발에 있어서, 로스팅 공정을 적용하는 것이 효과 적인 것으로 생각된다.

\section{감사의 글}

본 연구는 산림청 임업기술연구개발사업(과제번호: S111515L030100)의 지원에 의하여 이루어진 것으로 연구 비 지원기관에 감사드립니다.

\section{References}

1. Yuk, CS (1989) Coloured medicinal plants of Korea. Academybook, Seoul, Korea, p 301

2. Koichi T, Hideji I (1982) Isoflavonoids and the other constituents in callus tissues of Pueraria lobata. Chem pharm Bull, 30, 1496-1499

3. Chansakaow S, Ishikawa T, Sekine K, Okada M, Higushi Y, Kudo M, Chaichantipyuth C (2000) Isoflavonoids from Pueraria mirifica and their estrogenic activity. Planta Med, 66, 572-575

4. Oh MJ, Lee WY, Lee KS (1988) Purification and some properties of polyphenol oxidase from arrowroot. J Sci Food Agric, 31, 331-338
5. Park JH, Na HS, Kang KJ, Kim K, Kim SK (1998) Comparison of physicochemical properties of arrowroot starches harvested in different time. Korean J Food Sci Technol, 30, 97-102

6. Oh MJ, Lee KS, Son HY, Kim SY (1990) Antioxidative components of pueraria root. Korean J Food Sci Technol, 22, 793-798

7. Kuhm H, Lim JH, Lee EJ, Chang KS (2004) Rheological properties of gamma irradiated arrowroot (Pueraria thunbergina. B) starch. Korean J Food Sci Technol, 36, 740-743

8. Suzuki A, Hizukuri S, Takeda Y (1981) Physicochemical studies of Kuzu starch. Cereal Chem, 58, 286-290

9. Park JH, Han JS, Choi HK (1999) Effect on quality of pan-fired greentea by 1st pan firing time. Korean J Med Crop Sci, 7, 101-106

10. Chung HS, Kim JK, Youn KS (2006) Effects of roasting temperature on phycochemical properties of Job's tears (Coix lachryma jobi L. var ma-yeun) Powder and ExtractsKorean J Food Preserv, 13, 477-482

11. Hong MJ, Lee GD, Kim HK, Kwon JH (1998) Change in functional and sensory properties of Chicory roots induced by roasting processes. Korean J Food Sci Technol, 30, 413-418

12. Yoon SK, Kim WJ (1989) Effects of roasting conditions on quality and yields of barley tea. Korean J Food Sci Technol, 21, 575-582

13. Ha TY, Chun HS, Lee C, Kim YH, Han O (1999) Changes in physicochemical properties of steamed rice for Soong-Neung during roasting. Korean J Food Sci Technol, 31, 171-175

14. Lee YT, Seog HM, Kim SS, Kim KT, Hong HD (1984) Changes in physicochemical characteristics of immature barley kernels during roasting. Korean J Food Sci Technol, 26, 336-342

15. Ayatse JO, Eku OU, Ifon ET (1983) Chemical evaluation of the effect of roasting on the nutritive value of maize (Zea mays, Linn). Food Chem, 12, 135-147

16. Kunsch U, Scharer H, Patrian B, Hohn E, Conedera M, Sasella A, Jermini M, Jelmini G (2001) Effects of roasting on chemical composition and quality of different chestnut (Castanea Sativa Mill) varieties. J Sci Food Agric, 81, 1106-1112

17. Lee KS, Kim GH, Kim HH, Kim ES, Park HM, Oh MJ (2008) Quality characteristics of tea thermally processed from dried Ixeris dentata root. Korean J Food Preserv, 15, 524-531 
18. Hong MJ, Lee GD, Kim HK, Kwon JH (1998) Change in functional and sensory properties of Chicory roots induced by roasting processes. Korean J Food Sci Technol, 30, 413-418

19. Choi YH, Kim KH, Kang MY (2001) Varietal difference in processing and sensory characteristics of "Sikhe" in rice. Korean J Breed, 33, 65-72

20. Lee SH, Lee YR, Hwang IG, Woo KS, Kim KH, Kim KJ, Jeong HS (2009) Antioxidant activities and quality characteristics of germinated rough rice tea according to roasting temperature, time and leaching condition. Korean J Food Sci Technol, 41, 386-391

21. Kim HG, Kim GW, Oh H, Yoo SY, Kim YO, Oh MS (2011) Influence of roasting on the antioxidant activity of small black soybean (Glycine max L. Merrill). LWT-Food Sci Technol, 44, 992-998

22. Shin JH, Lee SJ, Seo JK, Cheon EW, Sung NJ (2008) Antioxidant activity of hot water extract from Yuza (Citrus junos Sieb ex Tanaka) peel. Korean J Life Sci, $18,1745-1751$ 